\title{
Merkel Cell Carcinoma cT2 TNM Finding v8
}

National Cancer Institute

\section{Source}

National Cancer Institute. Merkel Cell Carcinoma CT2 TNM Finding v8. NCI Thesaurus. Code $C 136845$

Merkel cell carcinoma with maximum clinical tumor diameter more than $2 \mathrm{~cm}$ but equal to or less than $5 \mathrm{~cm}$. (from AJCC 8th Ed.) 